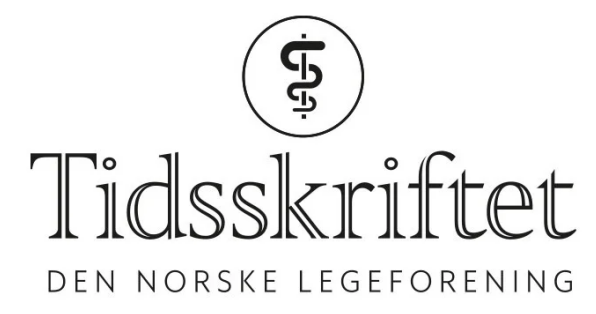

\title{
Behov for flere epidemispesialister
}

TIDLIGERE I TIDSSKRIFTET

JULIE DIDRIKSEN

julie.didriksen@tidsskriftet.no

Tidsskriftet

Lege og professor Axel Holst (1860-1931) tok i Tidsskriftet nr. 16/1918 til orde for at man måtte utdanne og ansette flere faste epidemispesialister, i tillegg til den ene legen i Norge som allerede jobbet med det. På denne tiden var det vanlig med lokale utbrudd av forskjellige sykdommer, deriblant tyfus, og hvis det skulle bekjempes, måtte det tas på alvor (Tidsskr Nor Lægeforen 1918; 38: 712-3). 


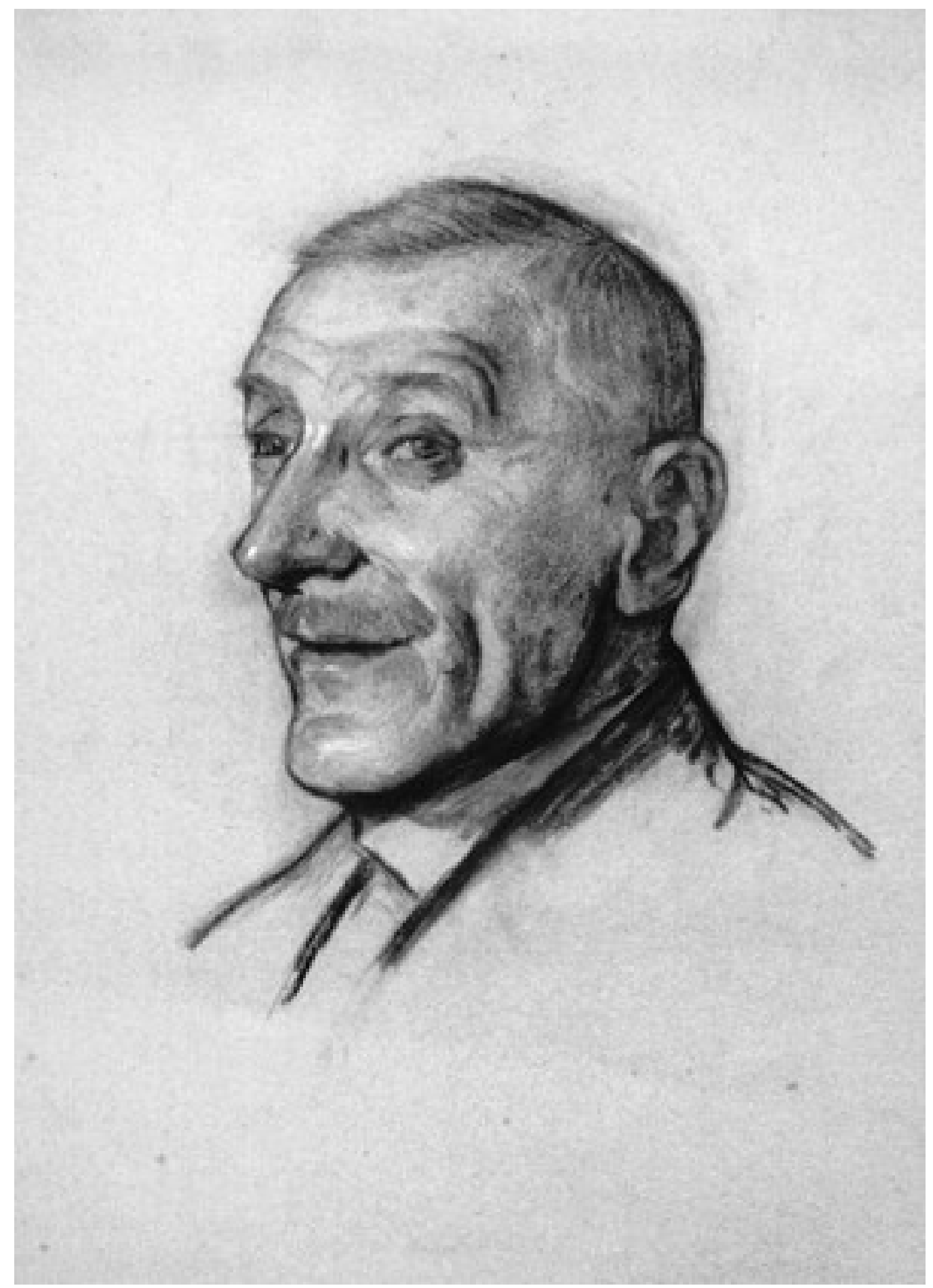

Axel Holst. Kulltegning fra 1916. Illustrasjon: Sinding-Larsen, Kristofer / Oslo Museum (CC BY-SA).

\section{Om ønskeligheten av at ansætte flere faste specialutdannede epidemilæger.}

\section{AV AXEL HOLST, PROFESSOR I HYGIENE.}

Paa en studiereise til Finmarken i 1916 var jeg en dags tid indom Mehavn. Ti jeg hadde fra forskjellige hold hørt, at der fra dette sted paa samme vis om i de foregaaende aar var drysset flere tyfustilfælder nedover kysten, helt til langt ned i Nordland. Ogsaa under mit ophold var der tyfus i Mehavn. Men det eneste, som jeg kunde konstatere, det var, at en specialutdannet læge med fuldt laboratorieutstyr maatte være forberedt paa at opholde sig der en længere tid, hvis man skulde faa rede paa smitteforholdene. 
Paa lignende maate gik det mig, da jg i fjor studerte hygienen paa landsbygden i egenskap av konstituert distriktslæge i Søndre Trondhjems amt.

Paa et sted, som laa ca. 30 kilometer fra min bolig, forefandt jeg efterdønningerne av en tyfusepidemi. Men da jeg til alle tider av døgnet blev kaldt ut til andre sygdomstilfælder i den øvrige del av det store distrikt, var det mig trods al god vilje ikke mulig at ofre den tid paa epidemien, som var nødvendig for at bringe smitteforholdene paa det rene. Bortset fra nogen Vidalske reaktioner maatte det medbragte laboratorieutstyr henstaa ubenyttet.

Ved at sammenholde disse erfaringer med hvad jeg oftere har hørt av landslæger, er jeg blit yderligere bestyrket i den anskuelse, som jeg i overensstemmelse med sanitetskaptein Zogbaums anførsler i «Tidsskriftet» for nogen tid siden længe har næret, nemlig at man ikke vil kunne gjennemføre den ønskelige bekjæmpelse av epidemier paa landsbygden uten ved at ansætte flere faste og specialutdannede epidemilæger. Av saadanne læger har vi for tiden bare en, nemlig docent Gram. Den gjerning, som han og hans forgjænger, nuværende stadsfysikus Geirsvold, paa det her omhandlede omraade har utført, har været overmaade stor. Men endog tilnærmelsesvis at utrede og stoppe kilderne til de epidemier i vort ustrakte land, som kræver en specialutdannet læge, det ligger langt utenfor en enkelt mands rækkeevne. Heller ikke synes der at være særdeles meget vundet ved at kombinere eventuelle nye epidemilægeposter med amtslægestilligerne i disses nuværende form. Saalænge nemlig disse er knyttet til distriktslægeembeder, vil deres indehavere bl.a. være saa bundet av den gjerning, som kræves utført i deres eget specielle distrikt, at de ikke naarsomhelst og kanske for længere tid ad gangen kan holde sig paa andre kanter av amtet.

\section{«Man ikke vil kunne gjennemføre den ønskelige bekjæmpelse av \\ epidemier paa landsbygden uten ved at anscette flere faste og \\ specialutdannede epidemilager»}

Skal denne sak ordnes paa en tilfredsstillende maate maa man faa flere poster av samme art som docent Grams. Det er ikke min mening, at man straks skal gaa igang med at oprette en slik post for hvert amt. Men postene faar oprettes efterhaanden. Forutsat at gagen blir rimelig - en forutsætning, som er absolut nødvendig - er det i høi grad glædelig, at man synes at skulle gjøre en begyndelse med at oprette en slik post for det vestfjeldske. Blir der saa i en nær fremtid ogsaa oprettet en post for de nordlige landsdele, hvor den sandelig likeledes vil komme godt med, vil vi unegtelig være et godt stykke paa vei.

Men efterhaanden om man indser den store nytte av disse stillinger, vil der formodentlig reise sig flere krav. Derfor maa jeg tilslut opkaste det spørsmaal: hvilke anstalter har vi, hvor de læger, som har interesse for den moderne epidemiologi, kan skaffe sig den nødvendige utdannelse? Dette spørsmaal har vel at merke ikke bare interesse for en ordning som den ovenfor nævnte. Enten det blir denne eller en anden ordning som vinder frem, er det nemlig en given sak, at vi trænger og yderligere vil trænge adskillig flere læger med epidemiologisk specialutdannelse, end vi hittil har hat. Svaret maa bli, at disse anstalter er epidemisykehusene. Kun der kan man nemlig baade faa den nødvendige bakteriologiske træning og studere de epidemiske sygdomme og deres diagnostiske vanskeligheter ved sykesengen. Ogsaa det sistnævnte studium er jo dog for en epidemilæge av største vigtighet. Og da belægget og dermed adgangen til dette studium er des mere omfattende, jo større belægget er, vil det netop være epidemisykehusene i vore største byer, som egner sig for øiemedet. Forsaavidt skulde derfor først og fremst Kristiania og Bergen komme i betragtning. (...)

Publisert: 4. januar 2022. Tidsskr Nor Legeforen. DOI: 10.4045/tidsskr.21.068o

(C) Tidsskrift for Den norske legeforening 2023. Lastet ned fra tidsskriftet.no 26. april 2023. 